\title{
NOTES
}

\section{THE POISONED CHALICE: IMPERIAL JUSTICE, MORAL RELATIVISM, AND THE ORIGINS OF INTERNATIONAL CRIMINAL LAW}

\author{
H. Christie*
}

The conquest of the earth, which mostly means the taking it away from those who have a different complexion or slightly flatter noses than ourselves, is not a pretty thing when you look into it too much.

— Joseph Conrad, Heart of Darkness ${ }^{1}$

That which is altogether just shalt thou follow,

-Deuteronomy $16: 20^{2}$

\section{INTRODUCTION}

The first serious attempt to criminalize war and prosecute individuals associated with war crimes and crimes against humanity took place at the close of World War I (WWI) at Versailles, under the investigation of a group

* The views and ideas expressed within this paper are mine alone and do not necessarily reflect the view of the University of Pittsburgh Law Review. In improving the clarity and expression of these thoughts I would like to thank Professor Vivian Curran, Professor Charles Jalloh, and Professor Bernard Hibbits for their critiques and contributions. Additionally, I would like to extend my deepest gratitude to Amy DiBella and Carver Koella for their thoughts and feedback and especially to Annie Christie for her continued support and untiring review of various drafts of this text.

1. Joseph CONRAD, HEART OF DARKNESs 8 (Everyman's Library ed. 1967) (1902).

2. Deuteronomy 16:20 (King James). 
entitled "The Commission on the Responsibility of the Authors of the War." The Versailles model of punitive redress focused on criminalizing the German state through a deprivation of basic sovereign rights, a limitation on economic growth potential, and an internationally administered demilitarization. Though ultimately unsuccessful at prosecuting Germany's Kaiser for violations of "international morality" and the sanctity of treaties, and blamed for the breakdown in the European order less than two decades later, this failed attempt laid a foundation for creating a judicial structure for pursuing the construction of international criminal law at the conclusion of the Second World War (WWII). ${ }^{4}$

In 1945, developments in the prosecution of individual violators by international courts came to the forefront of the international arena. ${ }^{5}$ It was hypothesized that ready acceptance of the parties to form this new type of judicial mechanism was, at least in part, a reaction to the failures of the Versailles model at the conclusion of WWI. ${ }^{6}$ The construction of the body of international criminal law utilized at Nuremberg ${ }^{7}$ was a first success and represented a sui generis method of addressing the dichotomatic friction between an area of law historically dominated by the authority of sovereign nations and the objective to prosecute individuals in that forum. ${ }^{8}$

As frequently addressed in academia today, international criminal law must balance many tensions besides that between its historical state framework and modern individualized objective. ${ }^{9}$ The judicial mechanisms face criticisms of prescribing victors' justice in a system of law that must define crimes for an international population: definitions which require determinations of the validity of relativistic moral perspectives. ${ }^{10}$ Additionally, there exists a certain amount of friction between the various articulated goals of this body of law, making simultaneous fulfillment of all the roles something

3. Robert Cryer, Hakan Friman, Darryl Robinson \& Elizabeth Wilmshurst, An Introduction to International Criminal LaW ANd Procedure 91-92 (2007).

4. Hans Kelsen, Principles of International Law 132 (2003); Gerry Simpson, Law, War \& CRIME 19 (2007).

5. Robert Cryer, Prosecuting International Crimes: Selectivity and the International Criminal Law Regime 36 (2005) [hereinafter Prosecuting].

6. Simpson, supra note 4, at 61 .

7. Although post-conflict courts had been suggested before this period, Nuremberg represented the first pragmatic attempt at addressing through legal channels the humanitarian violations carried out during conflicts. Although there were sharp criticisms of bias regarding the prosecutorial scope of the trials, the tribunal itself was a first step in addressing victor's justice in post conflict resolutions.

8. Simpson, supra note 4 , at 56-57.

9. CRYER ET AL., supra note 3, at 18-26.

10. See Prosecuting, supra note 5, at 245-62. 
of an Odyssean quest for the Court. ${ }^{11}$ Indeed, the entire body of international criminal law is precariously balanced over the fault lines where theoretical justice and the hard realities of law come together and meet: a definitive noman's land for law.

Legal scholars on the subject articulate the goals motivating the impetus and continued justification of international criminal law as including retribution, deterrence, history making, rehabilitation, and education, but at the forefront of this list is the duty of conferring a sense of justice to the population affected by atrocity. ${ }^{12}$ This sentiment has been echoed in the Tokyo proceedings of the International Military Tribunal (IMT) when Justice Röling of the Netherlands spoke to the function of the "principles of justice" within the obligations of the Tribunal itself saying, "the first duty of the Tribunal [is] to mete out justice." ${ }^{13}$ Additionally, in the 2003 Nikolic case at the International Criminal Tribunal for the Former Yugoslavia (ICTY), it was asserted that considerations of punishment at the international tribunal reflect "the calls for justice from the persons who have-directly or indirectly-been victims of the crimes." 14

The problem with justice as it concerns international criminal law is that, like many of the more theoretical pillars on which the law is generally constructed, it is a broad term with a number of meanings. ${ }^{15}$ At its broadest level, justice is defined as a derivative of fairness. ${ }^{16}$ The idea of "justice as fairness" has been articulated by Justice Jackson in his opening statement for the prosecution of the Nuremberg trials, and has been reaffirmed in many holdings of various international criminal tribunals. ${ }^{17}$ Even so, considering philosophical texts on the subject, the idea of fairness can be broken down

11. Hanna Arendt, Eichmann in Jerusalem: A Report on the Banality of Evil 5-9 (1963) (describing Arendt's frustrations with the history making function of the Court in the Eichmann trial, noting that the attempts to write history lead to banal trials).

12. CRYER ET AL., supra note 3, at 23-24.

13. United States v. Araki et al., International Military Tribunal for the Far East, Separate Opinion of Judge Röling (Nov. 24, 1948).

14. Prosecutor v. Momir Nikolić, Case No. IT.-02-60/2-S, T. Ch. I, Sentencing Judgment, 82 (Dec. 2, 2003).

15. See generally John Rawls, A Theory of Justice (rev. ed., The Belknap Press of Harvard University Press 1999) (1971) (exploring the generally morphological nature of the theory of justice).

16. Id. at 10 .

17. Robert H. Jackson, Opening Statement for the United States of America, On the Subject of International Military Tribunal No. I (Nov. 21, 1945), in Trial of the Major War Criminals Before the International Military Tribunal, Nuremberg (Nov. 14, 1945-Oct. 1, 1946) at 98-99; see Prosecutor v. Momir Nikolić, Case No. IT-02-60/2-S T.CH. I, Sentencing Judgment (Dec. 2, 2003); Prosecutor v. Akayesu, Case No. ICTR 96-4-T, Judgment (Feb. 9, 1998). 
further into several key factors. A common theme running through many national justice systems is the idea of justice as unbiased, as free from political influence, and as a law created in a neutral setting. ${ }^{18}$

Scholarly articles on the effectiveness of international criminal tribunals and the emerging body of international criminal law abound. ${ }^{19}$ Within this body of text, a common theme of questions emerges as to how justice is obtained, dispensed, and enforced. ${ }^{20}$ However, examinations of the origins and substantive definition of this central goal seem altogether lacking in relevance toward the fundamental idea of this theme. It seems important, before we ask ourselves how well this body of international criminal law functions in various fora, to pose the question: Is this representation of justice the most effective scheme we can apply to accomplish the defined goals of international criminal law? For a body of law with such a potentially broad basis of application and with such lofty ambitions as international justice, the more proper question should be: Whose justice are we administering?

Curiously, many scholars begin their study of the historical influences on this body of law with a discussion on the post-decolonization period, which involves questions on how nations with equal sovereign rights form and navigate relationships. ${ }^{21}$ However, the birth of international law, and thus, the structures and methodologies which influence international criminal law, stretch much further back than this limited historiography. ${ }^{22}$ Though

18. See generally Rawls, supra note 15; JeAn-Jacques Rousseau, The Social Contract And Discourses (G.D.H. Cole trans., Everyman's Library ed. 1993) (1913).

19. See Thomas Graditzky, Individual Criminal Responsibility for Violations of International Humanitarian Law Committed in Non-International Armed Conflicts, 322 InT'L Rev. Red Cross 29, 30 (1998); Christine M. Venter, Eliminating Fear Through Recreating Community in Rwanda: The Role of the Gacaca Courts, 13 Tex. Wesley an L. Rev. 577 (2007); Herbert D. Bowman, Letting the Big Fish Get Away: The United Nations Justice Effort in East Timor, 18 EMORY InT'L L. Rev. 371 (2004); Christopher Hale, Does the Evolution of International Criminal Law End with the ICC? The "Roaming ICC": A Model International Criminal Court of a State-Centric World of International Law, 35 DENV. J. InTL'L L. \& PoL'Y 429 (2007); Charles Chernor Jalloh, The Contribution of the Special Court for Sierra Leone to the Development of International Law, 15 RADIC 165 (2007); Charles Chernor Jalloh, Regionalizing International Criminal Law?, 9 InT'L CRim. L. Rev. 445 (2009); Christina M. Carroll, An Assessment of the Role and Effectiveness of the International Criminal Tribunal for Rwanda and the Rwandan National Justice System in Deal with the Mass Atrocities of 1994, 18 B.U. INT'L L.J. 163 (2000).

20. Venter, supra note 19, at 588; see also Simpson, supra note 4; Jide Nzelibe, Courting Genocide: The Unintended Effects of Humanitarian Intervention, 97 CAL. L. REV. 1171 (2009); Julian Ku \& Jide Nzelibe, Do International Criminal Tribunals Deter or Exacerbate Humanitarian Atrocities?, 84 WASH. U. L. REV. 777 (2007).

21. Ronald A. Brand, Sovereignty: The State, the Individual, and the International Legal System in the Twenty First Century, 25 Hastings Int'L \& Comp. L. Rev. 279 (2002).

22. See Antony Anghie, Imperialism, Sovereignty and the Making of International Law 29 (2005) (noting that the functional origins of international criminal law extend back at least until the 
potentially an unsavory point to illuminate, many of the structures of international criminal law have been influenced by the imperial period, an era marked by development of the idea of sovereign rights and access to those rights that was not based on equality as much as on hegemony. ${ }^{23}$ Reflected in the historical residue of hegemonic influence is the reality that the motive of the civilizing mission of the colonial era has been, and may continue to be, perpetuated within the legal structures of contemporary international criminal law.

Additionally, one of the main challenges to the justice international criminal law seeks to prescribe is the political influence inherent in the very nature of the body of law. ${ }^{24}$ Unlike other criminal law structures at the national level, when prosecuting a national military leader for war crimes or crimes against humanity on an international scale, it becomes impossible to divorce the political element. Therefore, in a definitively neo-colonialist flavor, the international legal arena leaves the use of force in international and civil relations untouchable as a sovereign prerogative but punishable after the fact, if such acts fall outside the accepted norms of the shared conception of international society. ${ }^{25}$ However, according to Justice Röling in 1945, such a unified society did not exist, and the "sense of shared moral purpose, cultural affinity and political direction necessary to the criminalization of sovereign behavior was absent." ${ }^{26}$ As such, the resulting system is inherently defined by the political motives of certain power players and simultaneously claims to produce a justice-product untouched by that very political influence.

To this end, this article seeks to explore the relation of the origins of international criminal law and the administration of "justice" based on these constraints. This analysis is addressed in three Parts. Part I considers the historical origins of the international law that has ultimately affected or become part of international criminal law. This Part concentrates on the elements that contributed directly to defining the boundaries of the international society of states, the conditions required for membership in that community, and the maturation of sovereign identity as it pertains to those considered outside this community. Considering sovereignty specifically, this Part examines the potential effects of the historical imperial nature on the post-decolonization interaction of states and other sovereign institutions of

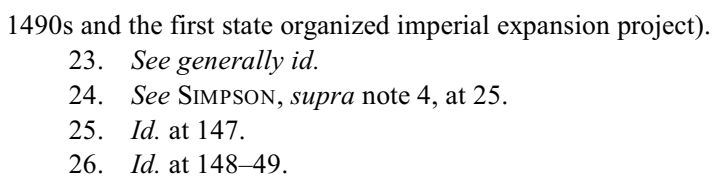


international law, illustrating that various colonial ideologies present in the administration and methodologies of international interactions were not likely discrete anomalies, corrected by decolonization efforts. ${ }^{27}$

Part II will then build off this historical view of the doctrine of sovereignty ${ }^{28}$ and its associated immunities to consider the modern underlying political elements potentially creating cultural bias behind contemporary international criminal law. This analysis will evaluate how these elements affect the functionality of this doctrine in today's international criminal courts by considering three contemporary issues. These issues will clarify the validity of existing accusations of the Court's neo-colonial approach to sovereign immunities. For modern legal scholars, these specific issues offer vignettes on the contemporary character and restrictions of the doctrine of sovereignty, thus illustrating international criminal law in light of both its historical influence and political nature.

In consideration of this analysis of past and contemporary influences manipulating the morphology of the rights associated with the doctrine of sovereignty, Part III will outline the prescriptive contribution of this Article. The challenges facing international criminal courts today and the concerns of legal scholars suggest that as international criminal law moves forward, it will be essential to acknowledge that both the historical precedent and political influence cannot be divorced from the specific nature of justice prescribed by these institutions. This is not to suggest that these influences make the tribunals ineffective or obsolete. It does, however, highlight the need, as international criminal law becomes more formalized, to limit and curb the expected functionality of the courts and tribunals in light of this nature. In particular, this Article seeks to illuminate the resulting injustice of a continued indifference of the international community toward the biases inherent in the political character and historical origins of international law.

\section{Developing International Criminal Law: A Historical Overview}

Historically, the birth of the law, which today governs interactions between states, was not based on a level playing field nor delineated on an objective view of national sovereignty. Rather, initial interaction among states

27. Antony Anghie, Colonialism and the Birth of International Institutions: Sovereignty, Economy, and the Mandate System of the League of Nations, 34 N.Y.U. J INT'L L. \& PoL. 513, 518 (2002) [hereinafter Colonialism].

28. See generally Jeffrey L. Dunoff et al., International Law Norms, Actors, Process: A Problem-Oriented Approach 107-09 (2d ed. 2006) (1960). 
was based on a Eurocentric concept of a civilized state which was accepted into the elite club of sovereign and the domination of those outside that sphere. ${ }^{29}$ Naturally, the concept of sovereignty has evolved through its acceptance in the customary international law of states. ${ }^{30}$ Regardless of the transformative quality of the concept of sovereignty, however, its prominent place and importance to international law is undoubted. ${ }^{31}$

To understand international criminal law, it is essential to analyze its historical precedent: the evolution of the law of nations. ${ }^{32}$ Despite the similar sources of these two bodies of law, the motives toward jurisprudential development differ in that international law was developed to address the rights and obligations of the state, whereas international criminal law seeks to define and address the duties deemed actionable for the individual within an international sphere. ${ }^{33}$ Perhaps because of this distinction, it has been argued that any corrupt elements utilized in the development of international law have been effectively purged and are thus of minimal consequence to considerations of current questions of the theoretical and substantive problems of international criminal law. ${ }^{34}$ However, the classical system, both from a philosophical and doctrinal perspective, has never been rejected in its entirety. ${ }^{35}$

Many of the most fundamental concepts of the state system still utilized were first developed from the need for a homogeneous method to control affairs between the independent states in Western Europe (which had, by the end of the reign of Frederic III in 1493, established themselves successfully) and the New World, into which these "developed" nations sought to expand. ${ }^{36}$ Although Hugo Grotius is most commonly acknowledged as the father of international law, Francisco de Vitoria, a sixteenth-century Spanish theologian and jurist, is in reality the source of several of the most important themes

29. ANGHIE, supra note 22, at 29.

30. See, e.g., The Paquete Habana, 175 U.S. 677, 686 (1900) (tracing the historical development of a rule of customary international law).

31. Brand, supra note 21, at 280-82 (noting that while the idea of sovereignty has changed over its historical development the presence of this concept is necessary to the continued success of international law).

32. CRYER ET AL., supra note 3, at 6-7.

33. Id. at $1-2$.

34. David Kennedy, International Law and the Nineteenth Century: History of an Illusion, 17 QUINNIPIAC L. REV. 99, 105 (1997).

35. Id. at 102.

36. Paul Keal, “Just Backward Children”: International Law and the Conquest of Non-European Peoples, 49.2 Australian J. Int’L Aff. 191, 191-92 (1995). 
currently utilized in this body of law. ${ }^{37}$ Though notable for his many contributions to the nature of relations between European powers and the indigenous peoples of colonized territories, the advancement that should be distinguished in reference to this Article is his articulation of the significance of law, and the importance of it underscoring any and all action in colonial enterprise. $^{38}$

Before Vitoria's repudiation of traditional techniques for characterizing relations between the Spanish and the indigenous populations of their colonial territories, these relationships were based on medieval jurisprudence giving the Pope universal authority. ${ }^{39}$ Vitoria argued that this power should shift from the Pope to the sovereign, and thus set into motion the question of the right to sovereignty. ${ }^{40}$ It was for this differentiation that Vitoria was credited as a defender of the native. However, in the same gesture and under the guise of sovereignty, Vitoria instigated a more acceptable "moral and legal basis for the subjugation" of these populations. ${ }^{41}$ For the indigenous Native population, Vitoria's sovereignty was just as elusive as a Christian status because although the idea of sovereignty was not linked with theological alignment, it was still awarded only to populations of "civilized" society. ${ }^{42}$

These first fledgling developments in international law would be articulated and solidified into a concept of sovereignty several hundred years later in the era which scholars refer to as the "long nineteenth century." 43 Whether based on economic, financial, or cultural motives, one of the most important components utilized by the colonizing power to justify the civilizing mission both to the indigenous population and the Western metropole was the

37. ANGHIE, supra note 22, at 13-31.

38. Id. at 16 .

39. Id. at 17 .

40. $I d$.

41. Keal, supra note 36 , at 197.

42. The main difference in the emphasis of secular systems of law and natural law was the instigation of the right of a nation to sovereignty. However, the Indians to whom Vitoria was applying this formulation ended up in much the same place under this new law. Vitoria argued that a sovereign must possess the power to declare and exercise all the rights of war. Unsurprisingly, the fundamental premise of his argument held that the Indians, because of their status as Saracens were inherently incapable of waging a just war, and thus the premise ensured that the Indians were excluded from the realm of sovereignty. This determination of sovereign rights effectively put the power of legal recognition of states into the hands of the political rulers of European powers. ANGHIE, supra note 22, at 23-31.

43. Historians of the period tend to see the nineteenth century as extending up to 1914 , as it is generally the commencement of the First World War, which marks the true end of this era. For the purposes of legal scholars and for this article we will consider the nineteenth-century in its final decades, from roughly 1870 (the culmination of the Franco-German war) into the commencement of WWI. See ERIC Hobsbawm, The Age of Empire, 1875-1914 (1987). 
law and the justice it would provide to the "backward peoples" 44 of these territories. ${ }^{45}$ Law offered both a justification and bargaining tool to the colonial powers for their actions and, inversely, it was through the expansion inspired by colonialism that international law became universal. ${ }^{46}$

The approach of the naturalists, described first by Vitoria and then expanded upon by legal and international scholars in the sixteenth and seventeenth centuries, asserted that the universal quality of international laws and rights, including that of sovereignty, derived from human reason and, as such, applied to all peoples. ${ }^{47}$ The changing world of the imperial nations put great pressure on the academic and legal community to craft these ideas into a more utile concept in light of the colonial mission. Positivist international theory suggests that there is a distinguishing characteristic between civilized states and non-civilized states that creates a duty of recognition and application of the sovereignty doctrine only to those states which comprise "the civilized family of nations." ${ }^{48}$ However, if the application of sovereignty was limited to civilized states, it created a presumption that European powers also had to assume an international responsibility and a role of greater governance over non-sovereign territories. ${ }^{49}$

Key positivist scholars of the time ${ }^{50}$ differentiated their methodology from their naturalist predecessors by describing their approach as scientific, mathematic, and precise, and "essentially sought to reconstruct the entire system of international law based on their new version of sovereignty doctrine." ${ }^{51}$ While the positivists narrowed the availability of sovereignty to indigenous populations, the power and authority of the sovereign was stressed

44. Keal, supra note 36, at 191; M.F. Lindley, The ACQuisition AND GovernMENT OF BACK WARD Territory in International LaW (Negro Universities Press ed. 1969) (1926).

45. Lauren Benton, A Search for Sovereignty: LaW and Geography in European Empires 1400-1900, at 7-9 (2010); see Stephane Beaulac, The Power of Language in the Making of International Law: The Word Sovereignty in Bodin and Vattel and the Myth of Westphalia (2004).

46. Colonialism, supra note 27 , at 516 .

47. Kennedy, supra note 34, at 137-38; Benton, supra note 45, at 131; James Brown Scott, The SPANISH ORIGin OF INTERNATIONAL LAW (1934).

48. Anghie, supra note 22 , at 35 .

49. Id. at 69 ("The direct involvement of European states in the whole process of governing resulted in a shift from the vulgar language of profit to that of order, proper governance and humanitarianism.").

50. John Westlake was the Whewell Professor of International Law in the University of Cambridge in 1894. His work covered the colonial question quite extensively. See John WestlaKe, Chapters on THE Principles of International Law (Cambridge University Press 1894). Henry Wheaton's text was also widely respected and used by positivists. See Henry Wheaton, Elements of International Law (Little, Brown \& Co., 1866).

51. ANGHIE, supra note 22, at 41 . 
so that even the customary international law of states could not touch his power. $^{52}$

At this zenith of power, the sovereign doctrine was given its supremacy by the presence of a society which consented to sovereign rule. However, this society was also specifically delineated and classified into civilized and noncivilized categories. The territorial lines were thus legally drawn, leaving the majority of sovereign states in Europe.$^{53}$ The responsibility of the European sovereign state as to non-sovereign territories and the division of the remaining territory among the colonizing empires was the central preoccupation of the Berlin Conference of $1884-1885 . .^{54}$ In order to assure peaceful relations among the European powers who were already vying for territorial control on the African continent, it became essential to diplomatically carve the region between the powers and organize the colonial "African scramble" of the period. ${ }^{55}$

Though international law did little to control the rising tensions of territorial greed among the European powers, it effectively justified the transformation of Africa into a conceptual terra nullius, ${ }^{56}$ redefining the sovereignty that had been promoted to the indigenous populations. In essence, it was "negotiated" away from them and nullified in the treaties that had previously resulted from these interactions based on the idea that these peoples were too primitive to understand the concept of their own sovereignty. ${ }^{57}$ Terra nullius offered both a clean slate on which to build the ever expanding empire and a way to assert control over the "rampant abuse by European adventurers of the treaty mechanism." 58 Thus, sovereignty was altered under political pressures by European power states to more easily suit their social and economic goals.

52. Emer de Vattel, The Law of Nations or Principles of Natural Law Applied to the Conduct and to the Affairs of Nationals and of Sovereigns (Charles G. Fenwick trans., 1916) (1758).

53. The kingdoms of Ethiopia, and Mali were sophisticated and powerful political entities, which temporarily retained their sovereign status even among the European states.

54. AngIE, supra note 22, at 90-93; A. Adu Boahen, Africa and the Colonial Challenge, in General History of Africa VII: Africa under Colonial Domination 1880-1935, at 29-31 (A. Adu Boahen ed., 1985).

55. ANGIE, supra note 22, at 90.

56. Keal, supra note 36, at 195; id. at 191.

57. ANGHIE, supra note 22 , at 91-94. Ironically, the treaty was deemed a tool too valuable to the imperialist powers to give up completely and so concept of sovereignty was mutilated again so that treaties continued to be utilized, as a notification method between imperial powers of territorial possession.

58. Id.; see also LindLEY, supra note 44, at 160-80. 
Despite the fact that no African representation was included in the proceedings of the Berlin Conference, the legal personality of the African tribes was addressed, but only to make the decision to permit the indigenous nation the ability to "consent" to territorial conquest permissible solely on the fulfillment of the requirements of a "civilized population." 59 A representative from the Lagos Observer reported with eerie accuracy at the conclusion of the conference: "Africa is helpless to prevent [such high-handed robbery] . . . . It is on cards that this 'Christian' business can only end, at no distant date, in the annihilation of the natives." ${ }^{\circ 0}$

Regarding those territories and tribal nations newly lacking in the ability to withhold consent from occupation, vis-à-vis sovereignty, the legal question for the colonizer was simple: the non-sovereign entity simply lacked legal standing to assert opposition. ${ }^{61}$ Not considering the few futile suggestions outside this standard in the international community, ${ }^{62}$ the distinction between civilized and non-civilized countries became the defining characteristic for those who received sovereign status under international law and those who did not. ${ }^{63}$ Non-European states were not only excluded from claims to sovereignty but from legal claims within the realm of international law as well. ${ }^{64}$

Though original colonial holdings shifted with the outcome of the First World War, ${ }^{65}$ the general usage of Eurocentric sovereignty remained unmodified until the onslaught of decolonization. ${ }^{66}$ The decolonization

59. ANGHIE, supra note 22, at 95 (arguing that this consent was particularly irregular and distorted from what we think of as consent today in theories of contract); Keal, supra note 36, at 200 (noting that free consent was necessary only from governments possessing "international validity," although the exact constraints of civilization depended on which legal scholar you spoke to at the conference).

60. J.F.A. Ajayi, Colonialism: An Episode in African History, in 1 Colonialism in Africa, 1870-1960: The History AND Politics of Colonialism, 1870-1914, at 497, 507 n.1 (L.H. Gann \& Peter Duignan eds., 1969) (quoting Lagos OBSERVER, Feb. 19, 1885) (explaining the relevance to the African nationals of the outcome of the Berlin Conference).

61. ANGHIE, supra note 22, at 34. See also Keal, supra note 36, at 200 (arguing that the consent of indigenous peoples sought through the treaty negation process was little more than a device to salve the conscience of the European mind).

62. See The Antelope, 23 U.S. 66, 121-22 (1825) (analyzing the inclusion of Africa within the law of nations and suggesting that America was required to respect this law as practiced in Africa).

63. Antony Anghie, Finding the Peripheries: Sovereignty and Colonialism in Nineteenth-Century International Law, 40 HARV. INT'L L.J. 1, 22 (1999).

64. ANGHIE, supra note 22, at 55. See also id.

65. See Colonialism, supra note 27, at 549 (noting that the Mandate System only applied to the territories "formerly annexed to Germany and the Ottoman Empire").

66. Siba N'Zatioula Grovogui, Sovereigns, Quasi Sovereigns, and Africans 179-81 (1996) (arguing that the idea of sovereign territorial rights and immunities were concrete ideas accepted in international law, rights that came only with the institutional features characterized by Western states that were sovereign). 
process was meant to transition various colonial problems into issues of the past. ${ }^{67}$ However, modern attempts of former colonial powers to assert jurisdictional authority over their colonies, and the resulting tenuous resolutions to those disputes, paint a different picture. ${ }^{68}$

It was presumed that decolonization was an end to an era in itself and that the new law, expressed in the United Nations Charter, would usher in a new age of universal principles. ${ }^{69}$ At the most basic level, during the process of decolonization, the rights and privileges related to sovereignty and selfdetermination remained grounded in historically and morally Western views. ${ }^{70}$ While the process of decolonization transformed the holders of political power from external states to the African nations themselves, the structures of domination that had been developed at the legal institutional level remained definitively biased toward hegemonic Western powers in the international forum. $^{71}$

The development of sovereign identities for colonial territories under the mandate system of the League of Nations was characterized by a slow and, at times, capricious process for the peoples seeking independence and state rights. ${ }^{72}$ Ironically, this process seemed heavily influenced by the previous Western classifications of "civilized countries" found in international law. ${ }^{73}$ The territories under the mandate system were classified according to their "degree of advancement," which was directly coupled with the Eurocentric quality of the material and moral well-being of the inhabitants of the mandate territories and the replacement of any lingering local legal mechanism with a system mirroring that of the previous colonizer, meaning a distinctly Westerndemocratic emphasis. ${ }^{74}$ Sovereignty would only be allotted to those states that

67. See Colonialism, supra note 27 , at 528-44.

68. DunOfF ET AL., supra note 28, at 667-70; CRYER ET AL., supra note 3, at 47-51 (including the well know examples of efforts by Spain to bring to trial Chile's former dictator, General Augusto Pinochet, for his part in human rights violations committed under his dictatorship, various trials in Belgium of Propagators of the Rwandan Genocide based on Belgium's now defunct Universal Jurisdiction Statute of 1993, and efforts by the Netherlands to indict Desire Bouterse, military commander in Suriname). 993.

69. Statute of the International Court of Justice art. 38, June 26, 1945, 59 Stat. 1055, 33 U.N.T.S.

70. ANGHIE, supra note 22, at 3 .

71. Id. at 2 .

72. Id.

73. League of Nations Covenant art. 22 paras. 1-2 (noting that the primary and substantive obligation undertaken by the mandatory power as stated in Article 22 of the League Covenant articulates that the concept was built on a "sacred trust of civilization." It is important also to note that the impetus for this humanitarian project was ultimately found in the work of Vitoria, who articulated the idea that the indigenous Indians could not have sovereignty because they were not "capable of controlling themselves.").

74. See U.N. Charter arts. 7, 39-41, 51; Colonialism, supra note 27, at 525-28. 
could prove themselves "Western enough" to deserve the right. As Anghie notes, "the very definition of international law retained the concept of civilization that had been used in the nineteenth century to exclude nonEuropean states." ${ }^{, 75}$ Through the decolonization process, the intense moral fervor of the Western-world was "embedded, instrumentalized, and institutionalized in the project of international criminal law." ${ }^{\text {"76 }}$ The decolonization process therefore became not a mechanism of justice between state actors but one used to perpetuate the myth of a universal right to sovereignty free from Western-centric influence.

However, the interest of powerful states, leading up to and during the decolonization period, obviously lacked the intention of permitting colonial nations the same access to the sovereign rights those Western states had enjoyed since the development of the concept. The international law system therefore became an expression of Western-centric self-interest. Interestingly, the imperial chapter in the history of international law is, for the most part, ${ }^{77}$ left entirely without historical reference. Most legal historians begin and end their historical analysis after the termination of WWII with the creation of the $\mathrm{UN}$ and with the question of organization among sovereign states, thus dismissing the hegemonic foundations of many of the key concepts in international law.

While the case history for this period is limited, ${ }^{78}$ the lack of substantive legal argument is not the important contribution that surfaces today in international law. The construction of the state-system negotiation techniques - the requirements to enter into treaty and the limitations on sovereign rights - remain the most enduring causative element. ${ }^{79}$ The shifting definition of sovereignty is one of the major problems that international criminal law is dealing with today. In the dialogue on these arguments, the continuation of Western powers' efforts to change the shape of sovereignty is visible both in the heterogeneous access to its protections and the malleability

75. Colonialism, supra note 27 , at 566 .

76. Simpson, supra note 4 , at 2.

77. At polar ends of the academic spectrum are Antony Anghie (see supra notes 22 and 27), who contests that the system of international law is still acting as a hegemonic extension of its imperial forefather, while David Kennedy (see supra note 34; David Kennedy, Sovereignty: Responding to Anghie and Aravamudan, 41 TEX. INT'L L.J. 465 (2006)) argues that all potentially negative aspects of this body of law have been purged.

78. See generally Kennedy, supra note 34 (illustrating in a rather one-sided argument the lack of cases from this period that remain well cited today).

79. BENTON, supra note 45 , at 279 (highlighting the idea that sovereignty has developed a definite space within the international discourse, even if that space is built more on a myth than a physical truth). 
of those protections regarding nationals disenchanted in the eyes of the promulgators of Western justice. ${ }^{80}$

\section{Sovereign Relativism: Neo-Colonial Functionality in Fundamental Theories of International Criminal Law}

International criminal law is often criticized as being compromised by political pressures. ${ }^{81}$ This delineation of the word "political" and the fear it evokes in the international justice arena is caused by the assumption of a required link between political influence and show trials ${ }^{82}$ However, where show trials are "politics unconstrained by trial or judicial process," ${ }^{\prime 3}$ the political influence associated with the nature of international criminal law is on a significantly more minor level. While international law is indeed more readily influenced by politics than a national system of criminal law would be, it can be easily differentiated from the famous "show trials" of history.

All justice is uniquely dependent to some degree on subjective perspective and thus on a type of manifested political opinion. ${ }^{84}$ Trials on manslaughter, negligence and traffic violations all require moral consensus on the designation of specific acts as "wrongs" and this decision involves impetus from social and legislative discretion. ${ }^{85}$ Likewise, by design, universal moral values are expressed in the work of international criminal law. Even at the time of the birth of international criminal law, specific choices were made to avoid scrutiny of Allied practices in the war, in the colonies, or in the Southern states of the United States. ${ }^{86}$ International criminal courts are selective and their choices manifest subjective influences. Even the choice of potential defendants raises suspicions that "the Court has been vested with the

80. See Dapo Akande, The Legal Nature of Security Council Referrals to the ICC and Its Impact on Al Bashir's Immunities, 7 J. InT'L CRIM. Just. 333 (2009); Paola Gaeta, Does President Al Bashir Enjoy Immunity from Arrest?, 7 J. INT'L CRIM. JUST. 315 (2009).

81. See generally Prosecuting, supra note 5, at 191-238; Simpson, supra note 4, at 11-30; Georges Abi-Saab, International Law and the International Community: The Long Road to Universality, in Essays in Honour of Wang Tiey 31 (Ronald St. John Macdonald ed., 1994); Onuma Yasuaki, When was the Law of International Society Born? - An Inquiry of the History of International Law from an Intercivilizational Perspective, 2 J. HIST. INT'L L. 1 (2000).

82. Harold Garfinkel, Conditions of Successful Degradation Ceremonies, 61 Ам. J. Soc. 420, 420 (1956); Simpson, supra note 4, at 12.

83. Simpson, supra note 4, at 12.

84. RAWLS, supra note 15 , at 47-64.

85. Id.

86. Simpson, supra note 4, at 145. 
task of applying international justice to international society's outsiders." ${ }^{97}$ However, in light of the accusation that the international arena lacks the moral consensus necessary to legitimize politically universal motivated decisions ${ }^{88}$ the effects of political influence have the potential to represent a neocolonialist movement in international criminal law by disregarding the rights of an individual in light of the international political goals of powerful nations.

\section{A. The Special Court for Sierra Leone and Jurisdictional Issues Surrounding the Indictment of Charles Taylor}

The case-by-case disparity in the definition and access to sovereign immunities in historical and contemporary contexts affects both the role of the state and the rights of the individual under international law and international criminal law. ${ }^{89}$ One recurring question in modern day examples of this issue is the degree of immunity enjoyed by Heads of State when sought for prosecutorial purposes by an international criminal court.

The Special Court for Sierra Leone (SCSL) was mandated under UN Security Council Resolution 1315 to try those leaders bearing "greatest responsibility" ${ }^{\prime 90}$ for crimes against humanity, war crimes, and other serious violations of international humanitarian law committed by various internal groups within Sierra Leone "during a decade of brutal conflict involving at least four armed factions." "The Sierra Leone Court, like other "mixed or hybrid" courts, was established pursuant to a bilateral treaty with the goal of grafting an international reach onto the already present judicial system of the country. ${ }^{92}$ However, UN-backed hybrid criminal courts are distinguished from the ad hoc tribunals for Rwanda and Yugoslavia in that they lack foundation through the Chapter VII powers of the Security Council. ${ }^{93}$

87. Id. at 17 .

88. Id. at 148 (referencing Justice Röling in 1945).

89. Brand, supra note 21, at 279.

90. Statute of the Special Court of Sierra Leone, art. I, I 1, Jan. 16, 2002 [hereinafter SCSL], available at $\mathrm{http} / / / \mathrm{www} . \mathrm{sc}-\mathrm{sl}$.org/LinkClick.aspx?fileticket=uClnd1MJeEw\%3d\&tabid=176.

91. Jalloh, supra note 19 , at 165.

92. See id. at 170-77 (noting that the goals for the methodology pursuant to this strategy include a cost effective court which would be culturally and physically closer to the conflict area, both points which were harsh criticisms of the ad hoc tribunals. Other courts constructed around this same organizational strategy include East Timor, Kosovo, Bosnia and Cambodia.).

93. C. Jalloh, Immunity From Prosecution for International Crimes: The Case of Charles Taylor at the Special Court for Sierra Leone, The American Society of International Law, Oct., 2004, http:// www.asil.org/insigh145.cfm. 
In a controversial move, in 2003 an indictment was issued against the then-President of Liberia, Charles Ghankay Taylor, for his role in various violent atrocities perpetuated by the Liberian government throughout a period of civil conflict. ${ }^{94}$ Taylor's counsel later filed a motion to quash the indictment based on his "immunity from criminal proceedings under customary international law as the sitting Head of State of Liberia at the time." 95 The argument for his case was twofold: the Special Court for Sierra Leone lacked the appropriate international power to secure this indictment, as this authority to act is provided exclusively through the direction of the Security Council of the UN under its Chapter VII powers. ${ }^{96}$ Secondly, Taylor argued that, in issuing an indictment clearly outside of the scope of the court's power, the indictment and warrant for arrest violated international law on immunity and sovereign equality. ${ }^{97}$ As per international law, Taylor's immunity claim shielded him from prosecution in his home state of Liberia and when he traveled outside that nation on official business of that state. ${ }^{98}$

Taylor's argument failed, and though the prosecution's response focused largely on the procedural issues of the submission, the substantive question on the power of the court to produce the indictment was addressed by citation to the customary international law of international criminal tribunals, specifically the International Criminal Court (ICC), which "denies immunity to Heads of States in respect of international crimes." 99 The immunity enjoyed by the acting Head of State of the sovereign nation of Liberia was disregarded by the Appeals Chamber through a legal analysis of the implicit designs of the Secretary-General and the President of the Security Council of the UN, demonstrating "the high level of involvement of the Security Council in the establishment of the Court." 100 However, there is a significant difference between a "high level of involvement" and authority secured through the utilization of Chapter VII powers. Though in this instance, the idea of sovereignty and the immunity offered under its protections was not in itself manipulated in light of the "civilized" western qualities of the nation; the

94. Prosecutor v. Charles Ghankay Taylor, Case No. SCSL-03-01, Indictment (Mar. 3, 2003), available at $\mathrm{http}: / / \mathrm{www} . \mathrm{sc}-\mathrm{sl}$.org/LinkClick.aspx?fileticket=1rn0bAAMvYM\%3d\&tabid=107.

95. Jalloh, supra note 93, at 165.

96. SCSL, supra note 90 , art. I, $\uparrow 1$ (arguing that this power is intended as a method for the UN to restore international peace and security, and as such are coercive in the sense of being binding on all UN Member States. The Special Court for Sierra Leone lacks this power.).

97. Jalloh, supra note 93.

98. Id.

99. Id.

100. Id. 
power necessary to pierce the shield of sovereignty was shifted from a direct usage of Chapter VII powers of the UN Security Council to a demonstrable level of involvement "including, but not limited to, approving the Statute of the Special Court and initiating and facilitating arrangements" on issues of funding. ${ }^{101}$

\section{B. The International Court of Justice Yerodia Decision}

Regarding the indictment and arrest warrant of Charles Taylor, it is essential to consider the 2000 holding of the International Court of Justice (ICJ) in the case concerning the Arrest Warrant of 11 April 2000, the Democratic Republic of Congo v. Belgium (Yerodia). ${ }^{102}$ Ironically, as one of the "worst human rights abusers during its colonial period," Belgium enacted one of the most aggressive universal jurisdiction statutes. ${ }^{103}$ Utilizing these provisions, the national court in Belgium issued an international arrest warrant charging the then-serving Minister of Foreign affairs for the Democratic Republic of Congo (DRC), Abdulaye Yerodia Ndombasi, with war crimes and crimes against humanity. ${ }^{104}$ When the DRC brought the matter before the ICJ, arguing that a national court had an international legal duty to recognize the immunity from criminal jurisdiction exercised by an acting Minister of Foreign Affairs, the ICJ agreed thereby a vote of thirteen to three. ${ }^{105}$ The Court's holding articulated that Belgium had breached its international duties, simply by "circulating internationally the arrest warrant," without considering the implications of potential further actions along this path. ${ }^{106}$

In its judgment, the ICJ considered the Statutes of the ICTR, ICTY and ICC as well as the father of these non-immunity provisions found in the Nuremberg Charter. ${ }^{107}$ The court clearly articulated under which provisions serious crimes of this nature could be prosecuted regardless of immunity:

First, persons may be tried in their home courts; second, they may be prosecuted if the State waives the immunity; third, they may be prosecuted, once they cease to

101. Id.

102. Case concerning the Arrest Warrant of 11 April 2000 (Dem. Rep. Congo v. Belg.), 2002 I.C.J. 121 (Feb. 14) [hereinafter Yerodia].

103. Thomas W. Donovan, Jurisdictional Relationships Between Nations and Their Former Colonies, 6 GonZ. J. INT'L L. 3 (2003).

104. $I d$.

105. $I d$.

106. Gaeta, supra note 80 , at 318 .

107. CRYER ET AL., supra note 3, at 436. 
hold office, for crimes committed in a private capacity; and fourth, they may be prosecuted before international criminal courts where such courts have jurisdiction. ${ }^{108}$

The fourth provision is essential to emphasize in regards both to the Taylor indictment by the SCSL and the arrest warrant issued by the ICC for the Sudanese President Omar Al Bashir. ${ }^{109}$ As discussed earlier, the indictment of Taylor could fit into only the fourth of these provisions, and then only if the international court seeking jurisdiction had successfully asserted jurisdiction over the individual. Where an international or national court exercises jurisdiction it is asserting a form of sovereignty. ${ }^{110}$ Where this jurisdiction is asserted by an international court or extraterritorially by national courts, the defined borders of these asserted sovereignties conflict. ${ }^{111}$ Although international law has yet to articulate bright-line rules on the hierarchy of jurisdictional claims (including jurisdiction sought under universal assertions), ${ }^{112}$ the immunities covered by sovereign status have long been defined and accepted under international customary law. ${ }^{113}$ The indictment of Taylor clearly falls outside of the restrictions articulated by the ICJ in this case as the immunities enjoyed by the sovereign actor were dismissed only through a neo-colonial-esque manipulation of the qualifications required to secure a dominant jurisdiction for the Sierra Leone Special Court.

Although the decision of the ICJ has been called into question regarding the lack of analysis on the particulars of the reach of sovereign immunities covering a foreign minister, ${ }^{114}$ this lack of nuance is discountable when considering the Court's holding in regard to the immunities covering acting Heads of State. The Court has also been criticized in the Yerodia decision for misbalancing the principle of sovereign immunity against international values. ${ }^{115}$ However, little emphasis has been placed on the importance of

108. Id. (citing to Yerodia, supra note 102, 61 (emphasis added)).

109. See supra and infra Parts II. A., II. B.

110. CRYER ET AL., supra note 3, at 37.

111. $I d$.

112. CRYer ET AL., supra note 3, at 44; see also Institut de Droit International, Seventeenth Commission, Universal Jurisdiction Over Genocide, Crimes Against Humanity and War Crimes, Krakow, 2 (2005) (arguing that although many states have attempted to utilize and thus define this jurisdiction, the new body of Universal Jurisdiction has yet to be solidified. The theory is that "States are entitled, but not obliged, to assert universal jurisdiction over war crimes, crimes against humanity, genocide and torture.").

113. DUNOFF ET AL., supra note 28, at 416-21.

114. CRYER ET AL., supra note 3, at 436.

115. Yerodia, supra note 102, at 84-89, 9 ๆ 70-85 (separate opinion of Judges Higgins, Kooijmans and Buergenthal). 
retaining the purity of sovereign immunity and its universal application for all countries, in contrast to international values as articulated only by those states that have joined specific international organizations, communities, and treaties. Notably, the holding of the Court lacked definition on the issues of the characteristics identifying a competent international court or tribunal and what grounds would justify the dispensing of personal immunities based on sovereignty. This lack of definition has caused and will continue to cause much confusion on this issue until a solidly defined approach can be officially adopted.

\section{The Immunities of Al Bashir in Light of Security Council Referrals}

A similar set of events, which considers the extension of sovereign immunity powers to non-Western Heads of State and which is still taking shape today, involves the referral by the UN Security Council to the ICC of the recent violence bordering on the level of human rights violation unfolding in Sudan. ${ }^{116}$ The ICC, like the mixed court of Sierra Leone, was not created under the Chapter VII powers of the Security Council, but acts as an international judicial body separate from the UN. ${ }^{117}$ Jurisdiction of the ICC Statute therefore does not directly attach to all member states of the UN but only to those parties who are signatories of the ICC Statute. ${ }^{118}$ However, the ICC is accepted in the international legal world as an international criminal court, regardless of its construction. ${ }^{119}$ The Court bases jurisdictional focus on three trigger mechanisms: State Party referral, Security Council referral under Chapter VII, and the initiative of the Prosecutor's own investigative powers. ${ }^{120}$ While there is nothing in the ICC Statute to expand the Court's jurisdiction over a lack of national enforcement against human rights violations, the potential for jurisdictional coverage over the international crimes, articulated

116. S.C. Res. 1593, U.N. Doc. S/RES/1593 (Mar. 31, 2005).

117. CRYER ET AL., supra note 3, at 119-24.

118. The Court has jurisdiction over only the "most serious crimes of international concern": genocide, crimes against humanity, war crimes and aggression; note that the Court however, cannot exercise jurisdiction over the crime of aggression until the Statute has been amended by the addition of a definition of that crime and the inclusion of preconditions for the ICC to take jurisdiction. Rome Statute of the International Criminal Court art. 5(1)-(2), July 17, 1998, 2187 U.N.T.S. 3 [hereinafter ICC Statute].

119. CRYER ET AL., supra note 3, at 124-33.

120. Lionel Yee, The International Criminal Court and the Security Council: Articles 13(b) and 16, in The International Criminal Court: The Making of the Rome Statute-Issues, Negotiations, RESUlts 143 (Roy S. Lee ed., 1999). 
in the Statute, is limited only by states not becoming signatory parties to the Statute. ${ }^{121}$

In 2004, acting on the request of the Security Council under Chapter VII powers, the ICC Pre-Trial Chamber issued an arrest warrant for the sitting President of Sudan. ${ }^{122}$ The request for surrender was circulated to not only the Sudanese authorities and those states who were parties to the Statute of the ICC but also to all UN Security Council members that were not state parties to the ICC Statute. ${ }^{123}$ Additionally, the ICC ordered that the warrant be circulated to any other state "which may be necessary for the arrest and surrender of Omar Al Bashir." "24 This action, in theory, placed under the jurisdictional reach of the ICC not only those states who had agreed to the ICC Statutes provisions but also those members of the UN who had not signed that agreement. Even if it is assumed that customary international law dictates that personal immunities of Heads of State are inapplicable in cases of criminal jurisdiction exercised by international criminal courts, the request for states to disregard sovereign immunity rights and surrender the requested individuals to the Court effectively reshapes the sovereign boundaries not only between the ICC and the state in question, but between that state and other states who might under this direction "lawfully" disregard this personal sovereign immunity. ${ }^{125}$

Again, it is important to note that the immunity protecting incumbent Heads of State from domestic charges of crimes on an international scale and prosecution for those crimes is clearly defined and accepted under customary international law. ${ }^{126}$ In the Yerodia case, the ICJ spoke directly to the reach of the ICC Statute in questions of immunities of Heads of State, holding that such immunities "shall not bar the Court from exercising its jurisdiction over such a person." ${ }^{127}$ Article 27(2) of the ICC Statute echoes this sentiment. ${ }^{128}$ The emphasis of its international court status signifies that unlike the national court of Belgium in the Yerodia case, the ICC has the authority to issue and circulate an international arrest warrant for the crimes under its jurisdictional

121. CRYER ET AL., supra note 3, at 135.

122. Prosecutor v. Omar Hassan Ahmad Al Bashir, Case No. ICC-02/05-01/09, Decision on the Prosecution's Application for a Warrant of Arrest (Mar. 4, 2009).

123. Gaeta, supra note 80 , at 316 .

124. $I d$.

125. See id.

126. Id.; DunOFF ET AL., supra note 28, at 416-21.

127. Yerodia, supra note 102 , at $26,961$.

128. ICC Statute, supra note 118, art. 27(2). 
reach, irrespective of personal immunities. ${ }^{129}$ However, the obligation of states acting under the order of an international criminal court in this scope has not been distinguished in either the Yerodia holding or the ICC Statute. ${ }^{130}$

Article 98(1) of the ICC Statute stipulates that unless the Court can obtain a waiver of immunity from a non-party state, it may not proceed with a request for surrender to a party-state if such actions would require the requested partystate to "act inconsistently with its obligations under international law with respect to immunities of a person or property of a third state." 131 This Article's provision articulates the accepted limits of state to state sovereign immunity, and limits the ICC's power to compel signatory states to act only with other states party to the Statute. While Sudan has signed the Statue, it has yet to ratify it. ${ }^{132}$ Additionally, the ICC has yet to obtain a waiver of the immunities from the Sudanese government, shielding President Al Bashir. ${ }^{133}$ Therefore, the Court clearly lacks the ability to compel states party to the Statute to comply with the request for the surrender of Al Bashir, and states can legally refuse to act under this obligation. Although this question is still undecided in the international field, the outcome of the Al Bashir arrest warrant will clearly illustrate whether international law intends to act within universal boundaries set and accepted in international fora, or if it will follow in the footsteps of its historical roots and alter the application and variation of the constraints of sovereign relations between states to procure a result sought by powerful states with political interests in the outcome of international criminal affairs.

\section{Preserving the Promise of International Criminal LaW}

In this era of international law, the principal actors are defined by sovereignty. ${ }^{134}$ Whether the parties consist of sovereign states, bound only by that to which they have consented, or international institutions, granted sovereign power through the negotiated consent of sovereign states, the underlying theme is the same: under customary international law primacy of the sovereign is unquestioned. ${ }^{135}$ Indeed, international criminal law adopted

129. Gaeta, supra note 80 , at 323.

130. Id. at 319 .

131. Id. at 328 .

132. The Rome Statute in the World, Coalition for the Int'L CRIM. Ct. (Nov. 2009), http://www.iccnow.org/documents/Signatures-Non_Signatures_and_Ratifications_of_the _RS_in_the_World_November_2009.pdf.

133. Gaeta, supra note 80 , at 329.

134. ANGHIE, supra note 22, at 33; Brand, supra note 21, at 279-80.

135. ANGHIE, supra note 22, at 33 . 
the idea of sovereign immunity as part of the accepted body of customary international law and has constructed its jurisdictional capacity in acquiescence of this accepted and significant tradition. ${ }^{136}$

Since the birth of modern international criminal courts at Nuremberg, one of the greatest threats to international criminal trials is the presence of political influence and the association of that influence with victor's justice. ${ }^{137}$ Nuremberg defendants attempted to cast their prosecution as the political theatre of the Allied forces even while Justice Röling conceded that the crimes for which the Japanese were being prosecuted were political in nature. ${ }^{138}$ Slobodan Milosevic, while being prosecuted at the International Criminal Tribunal for Yugoslavia, was quoted in the trial transcripts saying, "I never heard of indictments that resemble political pamphlets with poor, bad intentions." ${ }^{139}$ All of these accusations on the political nature of international criminal courts are meant to attack the validity of the justice prescribed by these institutions and insinuate that the outcome is based on the suggestion of the existence of a sub-textual political function and thus biased. ${ }^{140}$

Several prominent scholars, in consideration of these factors, maintain that the contemporary international criminal law system is flawed because of its historical origins and thus is fated to represent a mechanism which will ensure that the existing power distributions created by colonial maldistribution will remain not only unchanged but legitimized by an international legal body. ${ }^{141}$ However, these accusations fail to take into account the presence of historical bias throughout national legal systems and throughout the entire body of international relations. It would be a rare justice system indeed that could prove its construction was not, in some facet, biased in nature. ${ }^{142}$

136. See generally CRYER ET AL., supra note 3, at 426; DunOfF ET AL., supra note 28 , at 415.

137. Simpson, supra note 4, at 11-30 (noting that the historical presence of various show trials manifesting victors justice resolutions, served as effective deterrents to further international criminal law development).

138. Id. at 15.

139. Id. at 107.

140. Id. at 12 .

141. Id. at 147 (considering Justice Pal's opinions on international law); John R. Bolton, The Risks and Weaknesses of the International Criminal Court from America's Perspective, LAW \& ConTEMP. Probs., Winter 2001, at 167, 169.

142. Consider Jacques Vergès approach to defense in many of his famous cases but most notably in the Republic of the Congo v. France in which Vergès focused his opening statements on the nature of French colonial rule, the failure of the French authorities to indict President Chirac for alleged crimes of corruption, and the racial motivations underlying the French judicial system. Certain Criminal Proceedings in France (Congo v. Fr.), Order, 2003 I.C.J. 102 (June 17); see also ARENDT, supra note 11. 
Modern courts of international criminal law face the same problem that was faced by the positivist jurists in the colonial era: that sovereignty and the other institutions of international criminal law are not mathematical formulas that can be simply applied to a situation. Thus the definition of international crimes, ${ }^{143}$ the choice of specific parties as indictable, ${ }^{144}$ and the limitations of sovereign immunities ${ }^{145}$ will be, to some degree, subjective decisions. The differentiation between contemporary and colonial bias is the ultimate purpose sought in the utilization of the legal mechanism and the motive behind pursuing that purpose.

Likewise, critics who cite the political nature of international criminal law as a definitive flaw fail to take into account the fact that all criminal prosecution is in some measure politically motivated by "social power, prosecutorial discretion, or legislative choice." 146 The fact that any crime is dictated in some part by subjective moral views does not make the prosecution of that offense less socially valid. The real danger to the validity and effectiveness of any court is the operation of such an institution outside of the constraints of a homogeneous application of the law. ${ }^{147}$ The fault lies not necessarily in a distinctive role for politics in this arena of criminal justice, but with the displayed disregard for history, for context and for the political element altogether. ${ }^{148}$

What does it mean to say that international law consists of rules to which sovereigns have acquiesced when certain societies were denied sovereign status? How does international criminal law move forward successfully in light of the negative perception of its justice as a result of these influences? While several scholars would take the approach that no alteration is needed

143. For example, ICTR defined rape under the crimes against humanity criminality provision. See CRYER ET AL., supra note 3, at 208-10.

144. For example, scholars have raised the question as to why the conflict in Sierra Leone attracted international attention and the assistance of an international criminal court in addressing their conflictresolution while the similar situation in the neighboring country of Liberia did not warrant the same international interest. See generally Matiangai Sirleaf, Regional Approach to Transitional Justice? Examining The Special Court for Sierra Leone and the Truth \& Reconciliation Commission for Liberia, 21 Fla. J. INT'L L. 209 (2009).

145. Simpson, supra note 4, at 127 (noting that Saddam Hussein's objective international responsibility emerged only after his defeat in the 1990-91 Gulf War, regardless of the fact that he had previously used chemical weapons in the 1980's).

146. Id. at 14 .

147. Id. at $15-25$.

148. Id. at 157 (As both Osama bin Laden and the American President Bush have demonstrated, these are not strategies for success but further legal distortion.). 
to the current system, ${ }^{149}$ this article argues for the advancement of three prescriptive considerations. These include: reassessing and limiting the desired goals of international criminal law, emphasizing culturally relative judicial integration into international criminal law solutions, and furthering efforts to compile and homogenize the jurisprudential contributions of the various courts.

The acceptance and utilization of international criminal law was a precarious process. As the only tool available to access the entirely unaddressed field, it seems natural that it would be hoped that this instrument would be able to simultaneously fulfill the goals of all parties. However, these goals need to be reevaluated and narrowed in light of the limitations and flaws in these conflicting goals which experience has exposed. The most apparent manifestation of this conflict of goals is found in the desire for international courts to fill roles both as a history making instrument and as a nonbiased mechanism of justice. In the Eichmann trial, Hannah Arendt noted that the history writing function illegitimated the juridical function of the trial. ${ }^{150}$ As evidenced by that trial, it is difficult to resolve the different motives between these two goals. ${ }^{151}$ In order to preserve access to unbiased and fair justice, it becomes essential to "stream-line" the associated goals to purposes of a legal nature and leave purposes outside the legal sphere to public relations, educational, and academic institutions. ${ }^{152}$

One of the most essential components available to international criminal courts to combat existing allegations of neo-colonial motives is an ongoing, manifested commitment on the part of the courts toward integration of culturally relative elements. While Africa does offer the ICC the chance to promote international acceptance of the Court by showcasing an effective justice mechanism, ${ }^{153}$ the relation between the ICC and the African content offers the Court waters through which they should tread carefully. The historical relationship of the international community with the various nations of Africa has long been built on unequal footing. ${ }^{154}$ As outlined from colonial times through the decolonization process, the equality of legal mechanisms

149. Kennedy, supra note 34.

150. ARENDT, supra note 11 , at 5,9 .

151. Simpson, supra note 4, at 79-105.

152. Id. at 85 .

153. Jalloh, supra note 19 , at 448.

154. Boahen, supra note 54. 
and the interpretation of sovereign rights of these post-colonial nations have often been viewed through an imperial lens. ${ }^{155}$

By seeking legitimacy in judicial procedures in the context of postcolonized nations, the ICC and other international criminal courts risk perpetuating this imperial legacy if they are not cautious in their application of legal procedures and fearless in their search for justice of a truly universal and impartial nature. For these reasons, judicial solutions for international criminal law violations should explore the potential of analyzing culturally distinct issues on a case-by-case basis. As evidenced by the frustrations of Carla del Ponte, describing her prevention by political pressures from investigating military abuses carried out by the Rwandan Patriotic Front (RPF), crimes of this scale do not always neatly fit into the Nuremberg model of victim and criminal. ${ }^{156}$ As such, courts must make further efforts to design justice systems that forgo the use of Western-centric perspectives on chain-ofcommand, victim rehabilitation, and other culturally relative issues. It is in stipulating a single methodology, and thus, a single resulting idea of justice that the Court risks injuring its reputation as a universal body.

Above all, jurisdictional issues regarding the reach of the power of the ICC are still undefined and offer the developing body of international criminal law a broad field to remedy residual imperial tendencies, and limit the political influence of Western nations which might be interpreted as neocolonialist. For this reason, the preservation of the judicial contributions of the international courts and tribunals should be preserved, homogenized, and studied. As the Court seeks to pursue its global validity through the prosecution of human rights violations, the developing application of the Court's idea of universal jurisdiction and the boundaries of sovereign immunity are under scrutiny. ${ }^{157}$ However, if the jurisdictional limits of the ICC Statute are disregarded and reformed with each new instance to fit the jurisdictional needs of the prosecuting party, not only will this undermine the credibility and justice that the ICC hopes to mete out, but it will also effectively continue the trend of redefining the boundaries of international law to fit the Eurocentric visions of justice envisioned by those nations holding places of highest power within the international community.

155. Id.

156. Simpson, supra note 4 , at 17.

157. See Gaeta, supra note 80 ; Akande, supra note 80. 


\title{
CONCLUSION
}

In a conversation with the popular psychoanalyst Sigmund Freud on the topic of the necessity of war, Albert Einstein postulated that he could see only one way to deal with the superficial problem:

\begin{abstract}
The setting up, by international consent, of a legislative and judicial body to settle every conflict arising between nations. ... But here, at the outset, I come up against a difficulty; a tribunal is a human institution which, in proportion as the power at its disposal is inadequate to enforce its verdicts, is all the more prone to suffer these to be deflected by extrajudicial pressure . . . law and might inevitably go hand in hand, and juridical decisions approach more nearly the ideal justice demanded by the community (in whose name and interests these verdicts are pronounced) insofar as the community has effective power to compel respect of its juridical ideal. ... Thus I am led to my first axiom: The quest of international security involves the unconditional surrender by every nation, in a certain measure, of its liberty of action - its sovereignty that is to say - and it is clear beyond all doubt that no other road can lead to such security. ${ }^{158}$
\end{abstract}

Einstein, ever succinctly articulate on a myriad of subjects, seems to have described in minimalistic fashion the words Justice Jackson voiced at the opening of the Nuremburg trials. ${ }^{159}$ At that time, both personalities understood that the greatest challenge underlying the success and further development of international criminal law as an effective judicial mechanism would be its inherent threat to the positivist idea of sovereign rights. Under its objective definition, international criminal law addresses interstate conflict, head-ofstate sovereign immunity, suppression of enemies of the state, and many other areas commonly found solely under sovereign prerogative. ${ }^{160}$ The development of contemporary international criminal law mirrors the transformation of the international order in the twentieth-century. This evolution stresses the trend of nations moving from an order in which "equal status remain[s] unchanged by war or hostility, to one in which distinctions

158. Albert Einstein, Why War? The Correspondence Between Albert Einstein and Sigmund Freud (1978).

159. Robert H. Jackson, Opening Statement for the United States of America, On the Subject of International Military Tribunal No. I (Nov. 21, 1945), in 2 Trial of the Major WAR Criminals Before the International Military Tribunal, Nuremberg 14 November 1945-1 October 1946, 98-99 (1947) (stating "We must summon such detachment and intellectual integrity to our task that this Trial will commend itself to posterity as fulfilling humanity's aspirations to do justice.").

160. See generally Graditzky, supra note 19, at 30; Edoardo Greppi, The Evolution of Individual Criminal Responsibility under International law, 835 InT'L ReV. of the Red Cross 531 (1999). 
are drawn between states on the basis of their conformity to certain models of good government or their alignment with particular political projects."161

"Positivist jurisprudential theory is based on the notion of the primacy of the state; and, despite subsequent attempts to reformulate the foundations of international law," continues to operate as the basic premise of the international legal system. ${ }^{162}$ This rule of law, which delineated a limited access to sovereignty and independence, reflected European concepts of society, political organization, and economic interaction. ${ }^{163}$ It was these principles of Eurocentric conceptualization of sovereign power which subsequently became the law of nations. Verzijl might have best illustrated this point when he wrote:

there is one truth that is not open to denial or even to doubt, namely that the actual body of international law, as it stands today, not only is the product of the conscious activity of the European mind, but has also drawn its vital essence from a common source of beliefs, and in both of these aspects it is mainly of Western European origin. ${ }^{164}$

As Justice Jackson warned in his opening remarks in the Nuremburg trials, "[t]here is a dramatic disparity between the circumstances of the accusers and of the accused that might discredit our work if we should falter, in even minor matters, in being fair and temperate." 165 The possibility of this "dramatic disparity" influencing the justice prescribed by international criminal courts is a probability, on account of both the imperial origins of international law and the continued implicit influence of hegemonic political pressures. However, as Antonio Cassese, quoted by Justice Röling, so deftly pointed out when responding to the value of the courts in consideration of their potentially Westernized approach to justice, "half a pie is better than no pie at all." ${ }^{166}$

Indeed, international criminal law has proven itself just and ultimately functional in prescribing a constructive form of justice in more ways than it has evidenced a Machiavellian bias. In light of the growing contributions of non-governmental organizations (NGO's), transnational corporations, and

161. Simpson, supra note 4, at 142.

162. ANGHIE, supra note 22, at 33.

163. Id. at 56.

164. J.H.W. VerziJl, Western European Influence on the Foundations of International

LAW (1955) 1 International Relations 137; ANGHIE, supra note 22, at 35.

165. Jackson, supra note 159 , at 101.

166. Simpson, supra note 4, at 108. 
international organizations to the globalized marketplace and world arena, the positivist idea of sovereignty is diminishing in popularity. ${ }^{167}$ It is difficult to visualize international organization strategies without the territorial protections afforded by the doctrine, ${ }^{168}$ nevertheless, a shift in the bullet-proof immunities offered by sovereignty to those complicit in crimes deemed of international importance seems realistic. However, until that far-off date when the balance of power shifts from the hands of sovereign identities, international criminal law will be left to navigate the limitations of the doctrine.

In light of this, it is the duty of the international courts to acknowledge both the limitations of the law and the limitations of international criminal tribunals. The long and marketable lists of the goals of international criminal law need to be realistically reevaluated and narrowed in light of the true nature and restrictions of the court system. The jurisprudential contributions of the courts need to be compiled, homogenized, and studied so that clear and structured application of practices can assure that the revocation of sovereign immunities are not exploited under motives of political pressure, and as a manifestation of neo-colonialism. Lastly, due deference must be given to the element of cultural relativism. Although alternative measures to international criminal justice may not offer the global community the same closure and reprieve from guilt, the possibility of other options which might offer culturally specific success should be explored. Economic, rehabilitative and retributive goals as well as culturally specific ideas of justice should be assessed at the national level and the appropriate judicial mechanism prescribed, even if these alternatives prove to be less internationally fashionable.

International criminal law offers the world a potential of universal justice. However, if the issues of political influence and historically integrated bias are not addressed as they impact this maturing body of international law, we risk, as an international community, the very result which Justice Jackson foreshadowed in his opening statement for the prosecution of the Nuremberg Trials. "To pass these defendants a poisoned chalice is to put it to our own lips as well." "169

167. Kennedy, supra note 34, at 114-19; Brand, supra note 21.

168. Kennedy, supra note 34, at 112-14 (noting that even in his suggestion that a sovereign-based system should be eradicated Kennedy distinctly lacks realistic examples of alternative approaches).

169. Jackson, supra note 159, at 101. 